Spring 2005

\title{
Reinvigorating the Tradition of Symbolic Interactionism
}

Philip Manning

Cleveland State University, p.manning@csuohio.edu

Follow this and additional works at: https://engagedscholarship.csuohio.edu/clsoc_crim_facpub

Part of the Sociology Commons

How does access to this work benefit you? Let us know!

\section{Publisher's Statement}

Published as Manning, Philip. 2005. "Reinvigorating the Tradition of Symbolic Interactionism."

Symbolic Interaction 28(2):167-173. (c) 2006 by the Society for the Study of Symbolic Interaction. Copying and permissions notice: Authorization to copy this content beyond fair use (as specified in Sections 107 and 108 of the U. S. Copyright Law) for internal or personal use, or the internal or personal use of specific clients, is granted on behalf of the Society for the Study of Symbolic Interaction for libraries and other users, provided that they are registered with and pay the specified fee via Rightslink® on JSTOR (http://www.jstor.org/r/ucal) or directly with the Copyright Clearance Center, http://www.copyright.com.

\section{Original Citation}

Manning, Philip. 2005. "Reinvigorating the Tradition of Symbolic Interactionism." Symbolic Interaction 28(2):167-173.

\section{Repository Citation}

Manning, Philip, "Reinvigorating the Tradition of Symbolic Interactionism" (2005). Sociology \& Criminology Faculty Publications. 9.

https://engagedscholarship.csuohio.edu/clsoc_crim_facpub/9

This Article is brought to you for free and open access by the Sociology \& Criminology Department at EngagedScholarship@CSU. It has been accepted for inclusion in Sociology \& Criminology Faculty Publications by an authorized administrator of EngagedScholarship@CSU. For more information, please contact library.es@csuohio.edu. 


\title{
Reinvigorating the Tradition of Symbolic Interactionism
}

\author{
Philip Manning \\ Cleveland State University
}

I take Scheff's article to be in the honorable tradition of scholarly work that tries to preserve the best of the past while anticipating and contributing to the expansion of ideas. Scheff recognizes the pivotal importance of Goffman's work to symbolic interactionism in particular and to sociology in general and wants to expand our understanding of Goffman by revealing a poorly recognized debt. This debt connects Goffman to his predecessor Cooley, who had outlined a simple, powerful model of social interaction aptly named the "looking-glass self." In Scheff's view, recognizing this debt deepens our understanding of Goffman's dramaturgical approach, particularly the version of dramaturgy that is found in The Presentation of Self in Everyday Life (1959). This, in turn, is important because it opens the door to a sociology of emotions. As Scheff points out, Goffman pursued the sociology of emotions in a narrow way, focusing on embarrassment. Scheff advocates a wider view, which he associates with Hochschild's (2003) work. This exists at the intersection of symbolic interactionism and psychoanalysis. As an example of what can be harvested from this approach, Scheff presents an intriguing account of the role of shame in social life. Someone who has shame has, in Goffman's (1963) vocabulary, a "discredited self" because his or her stigma is publicly known. As Scheff and Goffman suggest, embarrassment is the recognition that shaming is occurring. Embarrassment marks the transition from a discreditable to a discredited self. By contrast, someone who feels guilt has only a "discreditable self" because no one else knows yet of the stigma. Thus shame is temporally connected to guilt. This was part of the fascination with guilt for Philip Rieff (1990), whose sociological investigation of guilt as a guiding and constraining emotion also led him back to Cooley.

Here I want to present four issues that I think are implicitly or explicitly raised by Scheff's interesting article. Their explication must itself be part of the reinvigorating of the tradition that Scheff has initiated. First, I wish to consider the role of the looking-glass self in Cooley's overall approach. Second, I will comment on weaknesses in Goffman's analysis of the self. Third, I will comment on the prospects 
for a synthesis of symbolic interactionist and psychoanalytic concerns. Fourth, I want to question Scheff's view that Goffman was a theorist of what he calls our "interior life" and sketch an alternative account of Goffman's project and achievement.

\section{THE LOOKING-GLASS SELF}

It is important to distinguish two different claims that Scheff could be making. The first is the broad claim that we can now understand Goffman's work better (although "better" will itself require careful explication) by recognizing his debt to Cooley. This broad claim makes Cooley Goffman's intellectual mentor, just as we might say, for example, that we can understand the work of an ethnomethodologist such as Melvin Pollner in a better way by recognizing his debt to Harold Garfinkel. By contrast, the narrow claim we could take from Scheff's article is that a particular concept in Cooley's work - the looking-glass self - helps us to understand a particular group of concepts in Goffman's work, all concerning dramaturgy. It would clearly be more revealing to establish the broad claim, but of course it will also be harder. The narrow claim should be easier to establish, but the potential payoff seems much smaller. I will look at each briefly.

Elsewhere (Manning 2005) I have argued that there are three themes that dominate Cooley's work: (1) a sociology of culture that serves as a political assessment of Progressivism, (2) a proto-symbolic interactionism, and (3) an account of "sympathetic introspection" as the "principal method of the social psychologist" (Cooley 1916:7). I do not want to dwell on the details of Cooley's sociology of culture, but it is worth recognizing that it contained both a political assessment and an evolutionary perspective that were central to the debates of his day. In defending a liberal, pluralist position, Cooley found himself at odds with both the pro-business doctrines found in the earlier work of, among his peers, William Sumner and the more left-leaning work of Ross, Small, Veblen, and others. As Rieff (1990:300) has made clear, Cooley's sociology of culture relied on a relativistic faith in the healing power of primary groups. It is of course the second strand in Cooley's work, which I am calling "proto symbolic interactionism" that is central to Scheff"s analysis. However, Cooley's thinking is still at several removes from the symbolic interactionist premises that we associate with Blumer. This is primarily because Cooley struggled to incorporate a theory of instinct into sociology. Cooley (1902 [1964]:4) referred to heredity as a "stream" and culture as a "road" running "along the bank" of the stream. Although he accepted the importance of both modes of transmission, he struggled to see how instincts could be assigned to either of them. His solution was to make instincts the result of an amalgam of heredity and culture. He therefore created a new term, "instinctive emotions," to convey this and named five types: anger, fear, maternal love, the sex drive, and a self-assertive drive for power (p. 25). In the second but not in the first edition of Human Nature and Social Order, Cooley explicitly tied this debate to a discussion of the merits of psychoanalysis, thereby confirming Scheff's general observation (famously it was Parsons's also) that symbolic 
interactionists and psychoanalysts have overlapping interests. Cooley then sought to connect his new analysis of instinctive emotions with a thoroughly sociologicaland implicitly Durkheimian - account of both the interconnection of the individual and society and our general interdependence.

Cooley's account of the looking-glass self is not really given pride of place in his work, and a reader of the first edition of Human Nature and Social Order in 1902 might easily miss the concept, as it is buried in the middle of a chapter in the middle of the book. However, Scheff is right that the looking-glass opens the door to the sociological investigation of our interior world, albeit very quietly. Cooley brought sociology to a crossroads when it had either to embrace some kind of psychoanalysis or to move away from it. This is because the three "principal elements" of the looking-glass self all involve the internal world of the individual: the first concerns the "imagination" of our appearance, the second the "imagination" of a judgment being made about us, and the third our sense of "self-feeling" (1902 [1964]:184). In each case, Cooley urges sociologists to engage in the study of internal worlds that, nearly a hundred years on, we are likely to see as some kind of object-relations, psychoanalytic project. The amazing possibilities here have been explored in an extraordinarily rich paper by Wiley (2003), in which he investigates the overlapping use of the mirror metaphor by Cooley and Lacan. Elliott (2001) has also recognized the same theoretical convergence.

Cooley's quiet, radical gesture led him to the methodology of "sympathetic introspection" in which he anticipated our contemporary debates about ethnography and autoethnography. Cooley was too reticent to engage in empirical work himself (unless you count the carpentry of which he was rightly proud). However, he urged his colleagues to go into the field and have "intimate contact with various sorts of persons ... allowing them to awake in [them] a life similar to their own" (1916:7).

These observations lead me to the conclusion that the broad claim that Cooley's cultural sociology helps us to understand Goffman's sociology is true only in a very general way. The narrow claim is more promising - that Cooley's concept of the looking-glass self helps us to understand Goffman's dramaturgical ideas. To anticipate the argument I will propose later, I think Scheff has found a very interesting way of identifying a weakness in Goffman that was not in Cooley. In arguing in this way, I am adapting Scheff's ideas. I take Goffman's unwillingness to follow the radical implications of Cooley's unexpectedly proto-psychoanalytic formulations to be the cause of some of his difficulties. It leads us to the complaint aired in many forms that Goffman is primarily an analyst of the presentation of self and not of the self. He therefore chose not to follow the logic of Cooley's position but instead sought to remain in the domain of the observable.

\section{GOFFMAN'S ANALYSIS OF THE SELF}

As I have just suggested, Goffman provided us with a model of the structure of social interaction, not a model of the performing agent. Wrong (1998:22-23) has 
suggested that Goffman and (other) symbolic interactionists fail to provide a convincing account of what motivates us to do whatever we do. In Rieff's mischievous phrase, Goffman has no interest in "interior decorating."

Other commentators have also noted that, like Durkheim, Goffman did not consider a person's inner world to be the appropriate subject matter of sociology. Lyman and Scott (1975:107) argue that Goffman's dramaturgical approach takes us out of people's heads and into public places. Williams (1998:154) makes a similar observation when he notes that Goffman treated a person's inner life as irrelevant and focused instead on "externally observable forms of conduct." Philosophers concur: Glover (1988:175) argues that Goffman mistakenly treats us as people with no "inner story," and MacIntyre (1982:30, 108-10) bemoans Goffman's amoral vision of social life in which the self is "liquidated" into its role-playing. Sennett (1970:36) puts the matter very concisely when he notes that in Goffman's world there are scenes but no plots.

And Goffman seemed quite happy to accept this judgment. In the unexpectedly useful Verhoeven interview (1993:322-24), Goffman said plainly that the individual is not "the central unit" and that he sees himself as an "ethnographer of small entities." He later added (in a passage reminiscent of Mead) that although reality is socially constructed, he does not think that "the individual himself or herself does much of the constructing." The thought is succinctly stated in the preface to Interaction Ritual where Goffman asserts, "Not, then, men and their moments. Rather moments and their men" (1967:3).

Recently, Archer (2000:317) made a similar point and found a new debt left unpaid by Goffman. This time it is not owed just to Cooley but to us all. Archer complains that Goffman's account of the presentation of self was limited to "presentational acts" and to their "public outworkings." "Goffman," Archer claimed, "owed us an account of the self, but left the bill unpaid" (p.317).

\section{SYMBOLIC INTERACTIONISM AND PSYCHOANALYSIS}

Although Scheff characterizes both Cooley and Goffman as "analysts of interior life," I think it is more apt to say that Cooley favored an introspective dimension of sociological work but Goffman chose to downplay it. Therefore, I believe Cooley's theorizing is important to our understanding of Goffman because he grasped the importance of the study of interior lives, whereas Goffman, like Durkheim, believed that this was not the concern of the sociologist.

Scheff is right when he points out that Goffman, like Blumer, opposed psychoanalysis as both a theory and a practice. Goffman's extensive knowledge of psychoanalysis had made him a kind of symbolic interactionist imperialist, leaving him to believe that psychoanalytic explanations are simply inferior to our own homespun ones. In this regard we are better placed than Goffman, and Scheff acknowledges that the work of Hochschild (2003) on the sociology of emotions is an important development for the field. I think that it is also worth recognizing that Chodorow 
(1999) and Prager (1998) have assisted in the reconstruction of a version of psychoanalysis that is compatible with - and valuable to - symbolic interactionism. Hochschild, Chodorow, and Prager allow us to see the missing link between Cooley and Goffman that many commentators allude to when they criticize Goffman's theory of the self.

Chodorow and Prager have double lives as both sociologists and psychoanalysts. They provide symbolic interactionists with a reconstructed, stripped-down psychoanalysis that has no clinical aspirations, deterministic metaphors, or developmental schemata. Instead, the concepts of transference and countertransference are brought center stage. As Chodorow (1999:26) puts it, "In my view, the discovery of transference constitutes, perhaps, the root psychoanalytic discovery." Transference is "the hypothesis and demonstration that our inner world of psychic reality helps to create, shape, and give meaning to the inter-subjective, social, and cultural worlds we inhabit. It is the original psychoanalytic vehicle for documenting for us the power of feelings" (Chodorow 1999:14). This formulation is eerily similar to Cooley's notion of the looking-glass self.

Cooley recognized the importance of sympathetic introspection, but his talents did not extend to empirical research, and so there is no demonstration from him of how to practice sociology. Contemporary versions of psychoanalysis that prioritize the investigation of transference are valuable tools enabling symbolic interactionists to realize the project that Cooley had only sketched out.

Earlier I suggested that Cooley anticipated our current debates about ethnography and autoethnography. The matter can now be put more forcefully: insofar as the autoethnographer participates in the activities, experiences, and emotions that are common to group membership, then the resulting analysis is a form of sympathetic introspection that is an investigation of the sociologist's own countertransference (Manning 2005).

\section{GOFFMAN'S PROJECTS}

Scheff argues that The Presentation of Self in Everyday Life (1959) is Goffman's "basic work." It is not easy to know exactly what is meant by this. It is true that the book was both his first major publication and a version of ideas developed in his doctoral dissertation (1953). It is also true, as Scheff suggests, that the book has had an enormous impact and has generated a sense of awe in many of its readers. However, I do not think that The Presentation of Self is Goffman's most important work. The arguments developed there are extended in Frame Analysis (1974), a book that Goffman probably intended to be his magnum opus.

However, in light of the comments in the previous section, I prefer to see (it is no more than this) Asylums (1961) as the litmus test for Goffman's sociology. This is because Goffman was able to do in this book what Cooley could not, namely, provide a case study of his ideas. In a brilliant methodological display, Goffman extended our understanding of ethnographic research, transforming the research agenda 
of symbolic interactionism away from the ethnography of places and onto the ethnography of concepts. Asylums is so well known to us that we can easily overlook the radical, revolutionary transformation of an ethnography of Saint Elizabeth's hospital in Washington, D.C., in the 1950s into an ethnography of the concept of the total institution (Manning 1992, 1999a, 1999b).

We have had more than forty years to absorb the implications of Goffman's radical, empirical transformation, and yet I believe we have only begun to understand the significance of Goffman's breakthrough. Nevertheless, the weaknesses that have been identified in Goffman's work in general resonate in Asylums also. The book contains little of Cooley's sympathetic introspection or the countertransference of Chodorow or Prager. The theoretical and empirical project that I take to be central to symbolic interactionism now concerns the fusion of Goffman's ethnographies of concepts with the analysis of transference and countertransference. Cooley will reemerge as an important element in the reconstruction. The result will be a blurring of the two genres ethnography and authoethnography. This blurring of genres was anticipated by Junker (1960) in his often overlooked textbook of qualitative methods and endorsed by Hughes.

For these reasons, Scheff is right to bring Cooley back to our attention and to make us reread Goffman in the light of Cooley. I have drawn a different set of conclusions from this rereading, but I owe Scheff a debt of gratitude for reinvigorating the tradition of symbolic interactionism. This, then, is the third of at least three debts still outstanding.

\section{REFERENCES}

Archer, Margaret. 2000. Being Human: The Problem of Agency. Cambridge: Cambridge University Press.

Chodorow. Nancy. 1999. The Power of Feelings. New Haven: Yale University Press.

Coolcy, Charles. 1916. Social Organization: A Study of the Larger Mind. Ncw York: Charles Scribner's Sons.

— 1927. Life and the Student: Roadside Notes on Human Nature, Society and Letters. New York: Alfred Knopf.

- [1902] 1964. Human Nature and Social Order. New York: Schocken Books.

Elliott. Anthony. 2001. Concepts of the Self. Cambridge: Polity Press.

Glover, Jonathan. 1988. I: The Philosophy and Pychology of Personal Identity. London: Allen Lanc, Penguin Press.

Goffman, Erving. 1959. The Presentation of Self in Everyday Life. Now York: Doubleday Anchor.

-1961a. Asylums. Harmondsworth: Penguin.

. 1961b. Encounters: Two Studies in the Sociology of Interaction. Indianapolis: BobbsMerrill.

1963. Stigma: Notes on the Management of Spoiled Identity. Harmondsworth: Penguin.

1967. Interaction Ritual: Essays on Face-to-Face Behavior. New York: Anchor.

- 1974. Frame Analysis: An Essay on the Organization of Experience. New York: Harper and Row.

Hochschild, Arlic. 2003. The Commercialization of Intimate Life: Notes from Home and Work. Berkeley: University of California Press. 
Junker, Buford. 1960. Field Work: An Introduction to the Social Sciences. Chicago: University of Chicago Press.

Lyman, Stanford and M. Scott. 1975. The Drama of Social Reality. New York: Oxford University Press.

MacIntyre, Alaisdair. 1982. After Virtue: A Study in Moral Theory. London: Duckworth.

Manning, Philip. 1992. Erving Goffman and Modern Sociology. Stanford: Stanford University Press.

1999a. "The Deinstitionalization and Deinstitutionalization of the Mentally Ill: Lessons from Goffman." Pp. 89-104 in Counseling and Therapeutic State, edited by J. Chriss. New York: Aldine de Gruyter.

1999b. "Ethnographic Coats and Tents." Pp. 104-18 in Goffman and Social Organization: Studies in a Sociological Legacy, cdited by G. Smith. London: Routledgc.

2005. Freud and American Sociology: The Remaking of Symbolic Interactionism. Cambridge: Polity Press.

Prager, Jeffrey. 1998. Presenting the Past: Psychoanalysis and the Sociology of Remembering. Cambridge, MA: Harvard University Press.

Ricff, Philip. 1990. The Feeling Intellect. Edited and with an introduction by J. Imber. Chicago: University of Chicago Press.

Scheff, Thomas J. 2005. "Looking-Glass Sclf: Goffman as Symbolic Interactionist." Symbolic Interaction $28(2)$.

Verhocven, Jeff. 1993. "An Intervicw with Erving Goffman. 1980." Research on Language and Social Interaction 26(3):317-48.

Wilcy, Norbert. 2003. "The Sclf as Self-Fulfilling Prophecy." Symbolic Interaction 26(4):501-14.

Williams, Robin. 1998. "Erving Goffman." Pp. 151-62 in Key Sociological Thinkers, edited by R. Stones. New York: New York. University Press.

Wrong, Dennis. 1998. The Modern Condition: Essays at Century's End. Stanford: Stanford University Press. 